American Journal of Agricultural and Biological Sciences 6 (4): 475-479, 2011

ISSN 1557-4989

(C) 2011 Science Publications

\title{
Assessment of Camel Meat Pollution with Trace Metals in Desert Area of Basra Province
}

\author{
${ }^{1}$ Sarmad G. Mohammed, ${ }^{2}$ Hassan T. Abdulsahib, \\ ${ }^{2}$ Ibrahim M. Jasim and ${ }^{3}$ Mushtak T. Jabbar \\ ${ }^{1}$ Department Food Science and Biotechnology, College of Agriculture, \\ ${ }^{2}$ Department Chemistry, Collage of science, \\ University of Basra, Basra, Iraq \\ ${ }^{3}$ Environmental Science and Engineering College, \\ Huazhong University of Science and Technology, Wuhan, China
}

\begin{abstract}
Problem statement: This study investigates the possibility of the camel meat pollution in south of Basra province (Iraq). Trace elements concentrations ( $\mathrm{Mg}, \mathrm{Fe}, \mathrm{Pb}$ and $\mathrm{Hg}$ ) were determined from different tissues of camel (neck, shoulder, plate, leg and loin) from two location in Basra governorate, Safwan and Al-Zubair. Approach: The study focused on the assessment of camel meat pollution on these locations with toxic elements which may caused by soil, water and plants which camel feed on. Results: The obtained results revealed that camel meat from area away from city gave higher concentrations of $\mathrm{Mg}, \mathrm{Fe}, \mathrm{Pb}$ and $\mathrm{Hg}$ comparing with those camels nearby city. Camel meat tissues differed in their content of $\mathrm{Mg}, \mathrm{Pb}, \mathrm{Fe}$ and $\mathrm{Hg}$; neck was higher in $\mathrm{Mg}$ and $\mathrm{Hg}$ content while leg was higher in their content of $\mathrm{Pb}$ and Fe comparing with the other tissues. Conclusion: The obtained results were compared with literature data and the results tended to be high.
\end{abstract}

Key words: Coefficient of Variance (CV), Standard Deviation (SD), camel meat pollution, trace metals, literature data, trace elements, toxic elements, mineral supplementation

\section{INTRODUCTION}

Camels are one of the most fundamental pillars of the national economy and food security for many countries in the world, because it occupies a very important role in providing an important part of human food, especially meat, in order to fulfill the shortfall in the increasing demand for meat due to the rapid growth of human population and the increase of the demand for the foodstuffs. Camel is an excellent source of high quality animal protein, provided with minimum resources.

The export of camel meat is now creating interest for the international meat market. Comparative technical information shows that the fat content of camel meat is considerably less than beef, low in cholesterol and high in protein. Camel meat is similar in taste and texture to beef (Williams, 1999). Camel meat, trace elements have an important role in its health and metabolism therefore it may be useful for the health of both camel and human (Higgins, 1986).

Essential elements are those if removed from diet result in consistent and reproducible impairment of physiological function (Mertz and Underwood, 1987). The deficiencies of these elements result from a combination of poor availability and low intake (Fennema, 1996).

There are 14 known essential trace elements for man, animals and plants; $\mathrm{Fe}, \mathrm{Cu}, \mathrm{Li}, \mathrm{Sn}, \mathrm{Ni}, \mathrm{V}, \mathrm{Mn}, \mathrm{Zn}$, Co, Mo, Se, Cr, B and Si (Bowen, 1979). Some elements such as $\mathrm{As}, \mathrm{Pb}, \mathrm{Cd}, \mathrm{Hg}$ and $\mathrm{Al}$ are frequently classified as toxic elements because of their reactions (Bowen, 1979).

Many trace elements occupy a central position in the effective operation of biological systems as functional components of metalloproteins and metalloenzymes. An assessment of deficiency or overloading states of essential trace elements is therefore of great importance in nutrition and clinical medicine (Iyengar, 1981). Iron and magnesium essential elements occur naturally in most fresh vegetables, meat, grains and eggs (Shang and Wang, 1997). While these metals are essential, they can be toxic and leads to very harmful effects when taken in excess.

The need for Iron and magnesium analysis in environmental and biochemical material has increased

Corresponding Author: Sarmad G. Mohammed, Department Food Science and Biotechnology, College of Agriculture,

University of Basra, Basrah, Iraq 
after reports on different roles of these metals in human health and diseases (Lieu et al., 2001).

Mercury and its compounds are included among the most toxic substances found in the environment (Renner, 1997) and it is exists in a large number of different physical and chemical forms with a wide range of physical, chemical and ecotoxicological properties that are of fundamental importance to its environmental behavior (Lambertsson et al., 2001). Lead in particular is a toxic caution and its toxic effects are well documented (Foulkes, 1990). Acute symptoms of lead poisoning include loss of appetite, vomiting, uncoordinated body movements, convulsions, coma and death (Thornton et al., 1990).

No analytical work has so far been undertaken on trace element content in meat of camel in Safwan and Al-Zubair. In this study data are presented for $\mathrm{Mg}, \mathrm{Fe}$, $\mathrm{Pb}$ and $\mathrm{Hg}$. in Safwan and Al-Zubair because no mineral supplementation for camel is used, intake of the elements and hence their levels will reflect the local soil and pasture content of these trace minerals.

\section{MATERIALS AND METHODS}

\section{Experimental:}

The study area: In order to study the levels of $\mathrm{Mg}, \mathrm{Pb}$, $\mathrm{Fe}$ and $\mathrm{Hg}$ in camel meat from Safwan and Al-Zubair city (nearby city and away from city) in south of Basra province. The Basra Province has been selected as a study area. Geographically, the Province is situated in the southern part of Iraq at the north western corner of the Arabian gulf, within longitude $4660-48^{\circ} 60^{\prime} \mathrm{E}$ and from latitude $2913-31^{\circ} 29^{\prime} \mathrm{N}$ with a total area of $19.070 \mathrm{~km}^{2}$ (Fig.1).

Sample preparation: During the period FebruaryApril (2011). The meat samples were collected from 12 mature camels varying age (2-5 years old) in Safwan and Al-Zubair(nearby city and away from city). These samples were transported hygienically to the Department of Food Sciences and Biotechnology, College of Agriculture, University of Basra, (Iraq), labeled properly and kept in a plastic bag and frozen at $-18^{\circ} \mathrm{C}$. After washing with distilled water samples were semi-thawed and about $2 \mathrm{gm}$ of meat were taken for mineralization. Digestion with nitric and perchloric acid was carried out, using method described by (Rashed, 2002).

Techniques of analysis: A flame atomic absorption spectrophotometer model (shimadzu AA-630-12) with an air-acetylene burner (slot dimensions $100 \times 0.62 \mathrm{~mm}$ ) was used for the determination of $\mathrm{Mg}, \mathrm{Fe}$ and $\mathrm{Pb}$.

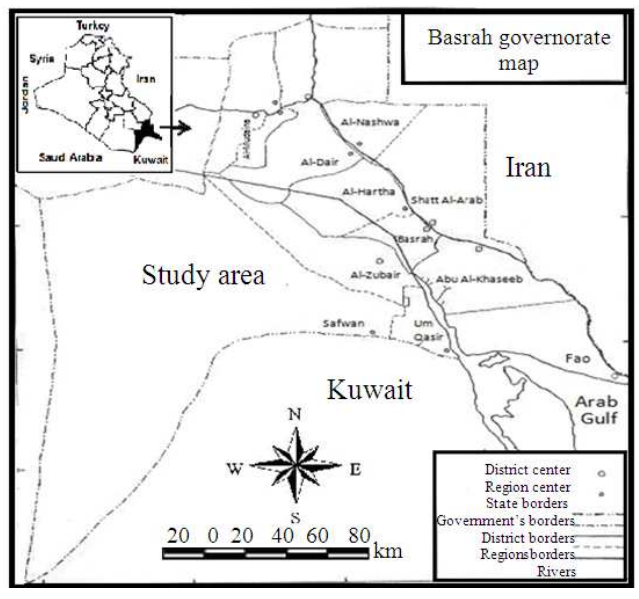

Fig. 1:General location of study area in the (Safwan and Al-Zubair) Basra Province and showing sampling stations

In addition, single element hollow cathode lamps for elements $\mathrm{Mg}, \mathrm{Fe}, \mathrm{Pb}$ and $\mathrm{Hg}$ were used at the recommended currents. For Mercury determination, cold vapor atomic absorption spectrometry was used.Conditions for the evolution of mercury atoms have been described elsewhere. The precision (expressed as Standard Deviation (SD) and Coefficient of Variance (CV) and the accuracy of the results were determined from six replications of the homogenized samples, giving a good standard of accuracy and precision for the analytical results.

Chemical composition: Moisture, protein, fat and ash were determined according to (AOAC, 1980).

Statistical analyses: Data were analyzed using SPSS (Nie, 1975) statistical software.

\section{RESULTS AND DISCUSSION}

The camel meat production represents about $0.7 \%$ of the world meat production, i.e., 216,315 tons (Anderson and Hoke, 1990).

Results can be converted to a dry mass on the basis of chemical composition of camel meat highlighted in Table 1. The obtained results show that camel tissues have nearly the same percentage of moisture content (74.29-76.57\%), while shoulder tissues were the lower in moisture $(70.16 \%)$. Protein content was the same in all tissues (16.38\%-19.45\%). Fat was significantly higher in shoulder tissues (11.22\%) comparing with the other tissues. Ash was significantly higher in neck (1.12\%) comparing with other tissues. 
Am. J. Agri. \& Biol. Sci., 6 (4): 475-479, 2011

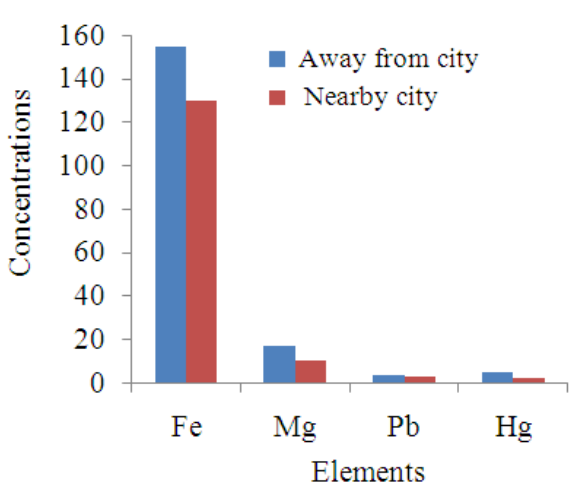

Fig. 2: Trace elements concentration in camel meat of Safwan (Fe, $\mathrm{Mg}$ and $\mathrm{Pb}$ in $\mu \mathrm{g} \backslash \mathrm{g}, \mathrm{Hg}$ in $\mathrm{ng} \backslash \mathrm{g}$ )

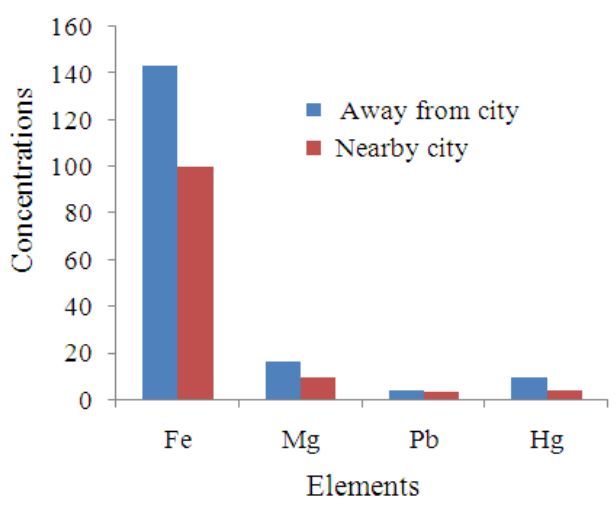

Fig. 3: Trace elements concentration in camel meat of $\mathrm{Al}-\mathrm{Zubair}(\mathrm{Fe}, \mathrm{Mg}$ and $\mathrm{Pb}$ in $\mu \mathrm{g} \backslash \mathrm{g}, \mathrm{Hg}$ in $\mathrm{ng} \backslash \mathrm{g}$ )

Table 1: Chemical composition of camel meat

\begin{tabular}{|c|c|c|c|c|}
\hline Meat sample & Moisture (\%) & Protein $(\%)$ & Fat $(\%)$ & Ash (\%) \\
\hline Neck & 76.16 & 17.72 & 3.77 & 1.12 \\
\hline Shoulder & 70.62 & 16.38 & 11.22 & 0.80 \\
\hline Plate & 76.57 & 19.45 & 2.20 & 0.75 \\
\hline Leg & 76.23 & 18.28 & 3.74 & 0.80 \\
\hline Loin & 74.29 & 19.12 & 4.51 & 0.65 \\
\hline
\end{tabular}

Table 2 and 3 summarize the elements content for different parts from camel meat of Safwan and AlZubair(nearby city and away from city). The results show that magnesium and mercury accumulate mainly in the neck for camel in the all study areas while the lowest concentrations were found in plate. For lead, leg contained the highest concentration in camel meat of Safwan (away from city) $\left(5.5 \pm 0.5 \mu \mathrm{g} \mathrm{g}^{-1}\right)$ while plate contained the lowest concentration in camel meat of AlZubair(nearby city) $\left(1.3 \pm 0.1 \mu \mathrm{g} \mathrm{g}^{-1}\right)$. The highest levels of iron was found in leg meat of Al-Zubair(away from city) camels $\left(350.0 \pm 25.0 \mu \mathrm{g} \mathrm{g}^{-1}\right)$. While the lowest concentrations were found in side meat of Safwan (nearby city) camels $\left(35.0 \pm 5.0 \mu \mathrm{g} \mathrm{g}^{-1}\right)$.

Generally; the camel meat from Safwan and AlZubair(away from city) revealed that the concentration of $\mathrm{Mg}, \mathrm{Fe}, \mathrm{Pb}$ and $\mathrm{Hg}$ were higher than those from Safwan and Al-Zubair(nearby city) as shown in Fig. 2 and 3. These high levels in the (away from city) camel meat were related to the presence of these elements in the desert plants and soil. Plants accumulate and concentrate various elements from the soil. Camels absorb other trace elements from the other grazing plants. Camels (away from city) depended on well water for drinking, this water is of high salinity and so this increases the concentrations of $\mathrm{Na}$ and $\mathrm{K}$ in the tissues and blood of camel. Camels (nearby city) tend to depend on man for their food. They are fed with hay, barley straw, millet, beans and clover. However, many camels graze naturally in the deserts. There, the natural food of the camels generally consists of the foliage of trees, shrubs and grass. When left to graze freely their food may include a large number of different species (Higgins, 1986). Trace element levels in camel tissues vary in accordance with the camel food and the pasture soils (Barrett and Larkinc, 1974).

The data presented above indicates the presence, in the modern environment of Safwan and Al-Zubair, of the concentrations of heavy metals $\mathrm{Hg}$ and $\mathrm{Pb}$. Accumulation of these metals from the soil through the plants and into the consumers is indicated.

These findings have implications for our understanding of the persistence of pollutants generated by mining and smelting in arid environments and for our understanding of the impact of such activities upon the ancient environment, as well as today. In the study area, in close juxtaposition, are found ancient industrial sites, an urban administrative centre and an intensely managed agricultural area, all of which would have required a considerable human workforce, which would have been exposed to the pollution through a variety of mechanisms. These mechanisms include direct ingestion of metal-rich dust on food, absorption into the lungs and accumulation via consumption of both animal and vegetable food, which may have been rich in heavy metals. Thus after several millennia of the operation of agencies such as atmospheric erosion (Pyatt and Birch, 1994; Gee et al., 1997; Maskall and Thornton, 1998; Zubillaga and Lavado, 2008; Akbari and Asadi, 2008). 
Am. J. Agri. \& Biol. Sci., 6 (4): 475-479, 2011

Table 2: Trace element concentration in camel meat of safwan ( $\mathrm{Fe}, \mathrm{Mg}$ and $\mathrm{Pb}$ in $\mu \mathrm{g} \backslash \mathrm{g}, \mathrm{Hg}$ in $\mathrm{ng} \backslash \mathrm{g}$ )

\begin{tabular}{|c|c|c|c|c|c|c|c|c|}
\hline \multirow[b]{2}{*}{ Meat sample } & \multicolumn{2}{|l|}{$\mathrm{Mg}$} & \multicolumn{2}{|l|}{$\mathrm{Pb}$} & \multicolumn{2}{|l|}{$\mathrm{Fe}$} & \multicolumn{2}{|l|}{$\mathrm{Hg}$} \\
\hline & Away from city & Nearby city & Away from city & Nearby city & Away from city & Nearby city & Away from city & Nearby city \\
\hline Neck & $26.2 \pm 1.10$ & $20.0 \pm 1.5$ & $3.0 \pm 1.2$ & $3.2 \pm 0.90$ & $100.0 \pm 2.00$ & $89.0 \pm .00$ & $3.0 \pm 0.50$ & $4.0 \pm 0.40$ \\
\hline Shoulder & $13.6 \pm 1.900$ & $10.3 \pm 3.7$ & $3.5 \pm 0.2$ & $1.5 \pm 0.20$ & $83.0 \pm 1.50$ & $67.0 \pm 3.50$ & $3.3 \pm 0.40$ & $3.0 \pm 0.20$ \\
\hline plate & $12.3 \pm 1.500$ & $14.5 \pm 2.5$ & $2.8 \pm 0.7$ & 2. $7 \pm 1.50$ & $44.0 \pm 9.70$ & $35.0 \pm 5.00$ & $2.0 \pm 0.10$ & $1.2 \pm 0.07$ \\
\hline Leg & $20.5 \pm 1.40$ & $16.4 \pm 1.0$ & $5.5 \pm 0.5$ & $3.7 \pm 0.50$ & $333.0 \pm 20.0$ & $290.0 \pm 15.0$ & $3.3 \pm 0.12$ & $3.8 \pm 0.20$ \\
\hline Loin & $16.4 \pm 1.000$ & $14.5 \pm 2.0$ & $3.9 \pm 0.3$ & $3.6 \pm 0.17$ & $283.0 \pm 17.0$ & $220.0 \pm 10.0$ & $2.0 \pm 0.10$ & $1.5 \pm 0.06$ \\
\hline
\end{tabular}

Table 3: Trace elements concentration in camel meat of $\mathrm{Al}-\mathrm{Zubair}(\mathrm{Fe}, \mathrm{Mg}$ and $\mathrm{Pb}$ in $\mu \mathrm{g} \backslash \mathrm{g}, \mathrm{Hg}$ in nglg)

\begin{tabular}{|c|c|c|c|c|c|c|c|c|}
\hline \multirow[b]{2}{*}{ Meat sample } & \multicolumn{2}{|l|}{$\mathrm{Mg}$} & \multicolumn{2}{|l|}{$\mathrm{Pb}$} & \multicolumn{2}{|l|}{$\mathrm{Fe}$} & \multicolumn{2}{|l|}{$\mathrm{Hg}$} \\
\hline & Away from city & Nearby city & Away from city & Nearby city & Away from city & Nearby city & Away from city & Nearby city \\
\hline Neck & $25.2 \pm 2.0$ & $19.5 \pm 3.00$ & $2.2 \pm 0.2$ & $3.0 \pm 0.20$ & $79.0 \pm 2.00$ & $85.0 \pm 5.0$ & $4.5 \pm 0.30$ & $2.5 \pm 0.4$ \\
\hline Shoulder & $16.5 \pm 1.5$ & $18.0 \pm 2.00$ & $2.9 \pm 0.3$ & $2.1 \pm 0.10$ & $87.0 \pm 3.00$ & $62.0 \pm 4.0$ & $4.0 \pm 0.50$ & $2.2 \pm 0.1$ \\
\hline plate & $14.3 \pm 2.0$ & $16.0 \pm 2.00$ & $2.0 \pm 0.2$ & $1.3 \pm 0.10$ & $36.0 \pm 3.50$ & $38.0 \pm 2.0$ & $1.5 \pm 0.10$ & $2.0 \pm 0.1$ \\
\hline Leg & $23.0 \pm 3.0$ & $21.0 \pm 1.00$ & $4.8 \pm 0.7$ & $4.5 \pm 0.60$ & $350.0 \pm 25.0$ & $230 . \pm 17.0$ & $2.5 \pm 0.12$ & $2.0 \pm 0.3$ \\
\hline Loin & $10.4 \pm 1.0$ & $7.50 \pm 1.0$ & $4.5 \pm 0.5$ & $3.5 \pm 0.3$ & $250.0 \pm 15.0$ & $200.0 \pm 8.0$ & $1.1 \pm 0.10$ & $1.8 \pm 0.2$ \\
\hline
\end{tabular}

Table 4: Concentrations of trace element in camel meat in present study comparing with different studies

Metal contents $(\mu \mathrm{g} / \mathrm{gm})$

\begin{tabular}{lllll} 
Location & $\mathrm{Fe}$ & $\mathrm{Mg}$ & $\mathrm{Pb}$ & References \\
\hline Egypt & $0.47-0.55$ & $0.27-0.38$ & - & Rashed (2002) \\
Aswan city & & & & \\
Syria & $26.8-33.60$ & $112.1-154.4$ & $0.214-0.511$ & Dyoub et al. \\
KSA & 295.2 & - & - & Al-Busadah (2003) \\
KSA & - & $500 \pm 30.00$ & Mofida and Khairia \\
USA & $27.6-33.6$ & - & & Anderson and Hoke (1990) \\
USA & - & - & 0.3 & Lawrie (1985) \\
Safwan city & $333.0 \pm 20.0$ & $26.2 \pm 1.10$ & $5.5 \pm 0.5$ & Present study \\
Al-Zubair city & $350.0 \pm 25.0$ & $25.2 \pm 2.00$ & $4.8 \pm 0.7$ Present study \\
\hline
\end{tabular}

In Table 4 literature data for levels of trace metals in camel meat are presented with exception of mercury. Concentrations of iron and magnesium in the camel meat from Egypt (Aswan city) (Rashed, 2002) were much lower compared to other studies. The high levels of iron were found in camel meat from Al-Zubair city while the high levels of magnesium were found in camel meat from KSA. Level of lead in camel meat from Syria were identical for those found in the camel meat from USA (Lawrie, 1985). In the camel meat samples from Safwan city the lead levels obtained by the present study were significantly higher than those found by other compared studies.

\section{CONCLUSION}

The large variation found between the various meat samples of camel is confirmed by literature data. Camel meat proved to be a good source of iron and magnesium. Lead and mercury levels were relatively high for all meat samples. These findings have implications for our understanding of the persistence of pollutants generated by mining and smelting in arid environments. The mechanisms include direct ingestion of metal-rich dust on food, absorption into the lungs and accumulation via consumption of both animal and vegetable food, which may have been rich in heavy metals. Thus after several millennia of the operation of agencies such as atmospheric erosion.

\section{REFERENCES}

Akbari, M. and A. Asadi, 2008. A comparative study of Iranian consumers' versus extension experts' attitudes towards Agricultural Organic Products (AOP). Am. J. Agric. Biol. Sci., 3: 551-558. DOI: 10.3844/ajabssp.2008.551.558

Al-Busadah. K.A., 2003. Trace-elements status in camel, cattle and sheep in Saudi Arabia. Pakistan J. Biol. Sci., 6: 1856-1859.

Anderson, B.A. and I.M. Hoke, 1990. Composition of Foods: Beef Products, Raw, Processed, Prepared. 1st Edn., United States Development of Agriculture, Washington, DC, USA.

AOAC, 1980. Official Methods of Analysis. 13th Edn., Association of Official Analytical Chemists, Washington, D.C., ISBN-13: 978-0935584141, pp: 1018.

Barrett, M.A. and P.J. Larkinc, 1974. Milk and Beef Production in the Tropics. 1st Edn., Oxford University Press, London, ISBN: 9780198594406 , pp: 245.

Bowen, H.J.M., 1979. Environmental Chemistry of the Elements. 1st Edn. Academic Press, London, ISBN: $9780121204501, \mathrm{pp}: 333$.

Fennema, O.R., 1996. Food Chemistry. 3rd Edn. Marcel Dekker Inc., New York, USA., ISBN: 9780824796914, pp: 1069.

Foulkes, E.C., 1990. Biological Effects of Heavy Metals. 2nd Edn., CRC Press, Florida, USA., ISBN: $9780849342424, \mathrm{pp}: 240$. 
Gee, J.C., D.C. Alsop and G.K. Aguirre, 1997. Effect of spatial normalization on analysis of functional data. Proc. SPIE, 3034: 312-322. DOI: 10.1117/12.274142

Higgins, A., 1986. The Camel in Health and Disease. 1st Edn. Bailliere Tindall Press, London, ISBN: 9780702011672, pp: 168.

Iyengar, G.V., 1981. Human healt and trace element research: Problems and prospects. Sci. Total Environ., 19: 105-109. DOI: 10.1016/00489697(81)90001-2

Lambertsson, L., E. Lundberg, M. Nilsson and W. Frech, 2001. Applications of enriched stable isotope tracers in combination with isotope dilution GC-ICP-MS to study mercury species transformation in sea sediments during in situ ethylation and determination. J. Anal. Atomic Spectrom., 16: 1296-1301. DOI: 10.1039/b106878b

Lawrie, R.A., 1985. Developments in Meat Science. 1st Edn., Elsevier Applied Science, London, ISBN: 9780853343615, pp: 299.

Lieu, P.T., M. Heiskala, P.A. Peterson and Y. Yang, 2001. The roles of iron in health and disease. Mol. Aspect. Med., 22: 1-87. DOI: 10.1016/S00982997(00)00006-6

Maskall, J.E. and I. Thornton, 1998. Chemical partitioning of heavy metals in soils, clays and rocks at historical lead smelting sites. Water, Air Soil Poll., 108: 391-409. DOI: 10.1023/A:1005029310495

Mertz, W. and E.J. Underwood, 1987. Trace Elements in Human and Animal Nutrition. 5th Edn., Academic Press, San Diego, ISBN: 9780124912519, pp: 480.
Nie, N.H., 1975. SPSS: Statistical Package for the Social Sciences. 2nd Edn., McGraw-Hill, New York, ISBN: 9780070465329, pp: 675.

Pyatt, F.B. and P. Birch, 1994. Atmospheric erosion of metalliferous spoil tips: Some localised effects. Polish J. Environ. Stud., 3: 51-53.

Rashed, M.N., 2002. Trace elements in camel tissues from a semi-arid region. Environmentalist, 22: 111118. DOI: $10.1023 / \mathrm{A}: 1015352828894$

Renner, R., 1997. Rethinking water quality standards for metals toxicity. Environ. Sci. Technol., 31: 466A-468A. DOI: 10.1021/es972517p

Shang, S. and H. Wang, 1997. Flame atomic absorption spectrometric determination of copper, zinc, calcium, magnesium and iron in fresh eggs using microvolume injection. Talanta, 44: 269-274. DOI: 10.1016/S0039-9140(96)02044-9

Thornton, I., D.J. Davies, J.M. Watt and M.J. Quinn, 1990. Lead exposure in young children from dust and soil in the United Kingdom. Environ. Health Perspect., 89: 55-60. DOI: 10.1289/ehp.908955 PMID: 2088756

Williams, O.J., 1999. Capture and Handling of Camels Destined for the Abattoir. 1st Edn., Central Australian Camel Industry Association, Alice Springs, N.T., ISBN: 0957705409, pp: 16.

Zubillaga, M.S. and R.S. Lavado, 2008. Accumulation and movement of four potentially toxic elements in soils throughout five years, during and after biosolid application. Am. J. Environ. Sci., 4: 576582. DOI: 10.3844/ajessp.2008.576.582 